\title{
SURVIVAL AND VIABILITY OF BRADYRHIZOBIUM JAPONICUM IN DIFFERENT LIQUID MEDIUM
}

\author{
PREŽIVLJAVANJE I ODRŽIVOST BRADYRHIZOBIUM \\ JAPONICUM U RAZLIČITIM TEKUĆIM MEDIJIMA
}

\author{
Gabriella Kanižai Šarić, K. Prtenjača, Ivana Majić
}

\begin{abstract}
The microbiological inoculants present on the market come in various formulations and forms. Inoculants used in pre-sowing bacterization of legumes in our country are traditionally prepared on peat as the highest quality carrier of bacteria. However, the requirements of the manufacturer are focused on liquid forms of inoculants. Therefore, the aim of this paper is to determine the optimal composition of the liquid medium that will support the growth of Bradyrhizobium japonicum, the soybean symbiont. Three liquid nutrient medium formulations were included in the study: mannitol-yeast medium, modified mannitol-yeast medium, and glycerol medium stored at two temperatures $\left(4\right.$ and $25{ }^{\circ} \mathrm{C}$ ), and B. japonicum cell viability was determined over 6 months. The results showed that the largest number of rhizobia (on average $4 \times 10^{9}$ zo $9 \times 10^{8}$ ) was obtained on yeast-mannitol medium at $4{ }^{\circ} \mathrm{C}$ as well as on modified yeast mannitol medium where their number remained constant throughout the storage time and was $5 \times 10^{7} \mathrm{cfu} \mathrm{ml}^{-1}$ at $25{ }^{\circ} \mathrm{C}$. Further research should include testing other rhizobial protectors in order to increase the number of viable cells in longer time periods.
\end{abstract}

Key words: soybean, liquid inoculants, protective compounds, temperature, storage time

\section{SAŽETAK}

Mikrobiološki preparati prisutni na tržištu dolaze u različitim formulacijama i oblicima. Inokulanti koji se primjenjuju u predsjetvenoj bakterizaciji leguminoza u našoj zemlji se tradicionalno pripravljaju na tresetnom kao najkvalitetnijem nosaču bakterija, međutim zahtjevi proizvođača su usmjereni na njihove tekuće forme. Stoga je cilj ovog rada utvrditi optimalan sastav tekuće podloge koja će podupirati rast Bradyrhizobium japonicum, simbionta 
soje. U istraživanje su uključene tri formulacije tekuće hranjive podloge: manitol-kvasac podloga, modificirana YM (yeast-mannitol) podloga i podloga s glicerolom koje su pohranjene na dvije temperature $\left(4\right.$ i $\left.25{ }^{\circ} \mathrm{C}\right)$ te je vijabilnost stanica $B$. japonicum utvrđena kroz 6 mjeseci. Rezultati pokazuju da je najveći broj rizobija (u prosjeku od $4 \times 10^{9}$ do $9 \times 10^{8}$ ) dobiven na kvasac-manitolovoj podlozi na $4{ }^{\circ} \mathrm{C}$ te na modificiranoj kvasac manitol podlozi gdje je njihov broj ostao konstantan tijekom cijelog vremena skladištenja i iznosio je $5 \times 10^{7} \mathrm{cfu} \mathrm{ml}^{-1}$ na $25^{\circ} \mathrm{C}$. Daljnja istraživanja bi trebala biti usmjerena na ispitivanje i drugih protektora rizobija u cilju povećanja vijabilnosti stanica i u dužem vremenskom periodu.

Ključne riječi: soja, tekući inokulanti, protektivne tvari, temperatura, vrijeme skladištenja

\section{INTRODUCTION}

Soybean (Glycine max L. Merr.) is the most commonly sown legume worldwide and represents a nutritionally essential part of the humans and domestic animals diets due to high grain protein content (Hungria and Mendes, 2015). Pre-sowing bacterization of soybean seeds with inoculants present on the market ensures successful infection and nodulation of soybean roots with effective strains of Bradyrhizobium japonicum. This measure is a standard agricultural practice because it allows the fixation of $0-450 \mathrm{~kg}$ of atmospheric $\mathrm{N} \mathrm{ha}^{-1}$ per year (Ormeño-Orrillo et al., 2012). The quality of all inoculants is determined by a number of factors and the most important is to ensure a large number of living cells of rhizobium bacteria (greater than $2 \times 10^{9}$ per $\mathrm{g}^{-1}$ ) without or with minimal contamination (Lupwayi et al., 2000). In addition, B. japonicum strains incorporated into the inoculant must be highly effective, viable, and retain their properties during storage but must also be tolerant to stressful conditions such as acidity, drought, high temperature and chemical pesticides (Lupwayi et al., 2000.; Ben Rebah et al., 2007.). Furthermore, the quality of the inoculant is determined by they efficiency and easy application, appropriate product shelf life, proper packaging and clear instructions for use on each package (Lupwayi et al., 2000). Inoculants carrier must satisfy certain criteria, they must be: available, uniform in composition, cheap in price, nontoxic to the bacteria, with high water retaining capacity and with good nutrient content to allow bacterial growth (Hungria et al.. 2005). Peat are the most commonly used carrier of solid rhizobial inoculants because it 
satisfies all the above mentioned properties. However, peat stocks are limited and this technology requires grinding, drying, neutralization and sterilization (Hungria et al., 2005). Researchers are investigating the properties of other potential carriers of inorganic (perlite, vermiculite) or organic (compost) origin (Temprano et al.; 2002, Albareda et al., 2008; Blažinkov et al., 2015). Liquid inoculants are easier to handle but bacterial survival is lower (Singleton et al., 2002.; Albareda et al., 2008). This type of inoculant include a various broth formulations. The application of protective materials such as: polyvinylpyrrolidone (PVP), polyethylene glycol (PEG), gum arabic glycerol, glucose, mannitol, trehalos or FeEDTA improve the quality of liquid inoculants, protect bacterial cells and allow better adhesion to seeds (Temprano i sur., 2002.; Singleton et al., 2002.; Tittabutr et al., 2007). The aim of study was to determine efficacy of yeast-mannitol medium as standard medium for rhizobial growth and two modified medium with protective compounds on viability of B. japonicum cell incubated on two temperatures $\left(4\right.$ and $\left.25{ }^{\circ} \mathrm{C}\right)$ over a period of 6 months.

\section{MATERIALS AND METHODS}

An in vitro experiment was performed which included Bradyrhizobium japonicum DSM 1755. Pure cultures of the tested strain were inoculated on solid yeast-mannitol medium (Vincent, 1970), and incubated for 7 days at $28{ }^{\circ} \mathrm{C}$. The grown colonies were transferred to a (I.) liqiud yeast-mannitol medium (YM) (Vincent, 1970), (II.) modified yeast-mannitol medium (mannitol $1 \mathrm{~g}, \mathrm{~K}_{2} \mathrm{HPO}_{4} 0.5 \mathrm{~g}, \mathrm{MgSO}_{4} \times 7 \mathrm{H}_{2} 00.2 \mathrm{~g}, \mathrm{NaCl} 0.2 \mathrm{~g}$, yeast $0.1 \mathrm{~g}$, PVP 20g (MYM) and (III.) glycerol medium (glycerolum $12 \mathrm{ml}$, mannitol $1 \mathrm{~g}$, $\mathrm{K}_{2} \mathrm{HPO}_{4} 0.8 \mathrm{~g}, \mathrm{MgSO}_{4} \times 7 \mathrm{H}_{2} \mathrm{O} 0.5, \mathrm{NaCl} 0.1 \mathrm{~g}$, yeast $2 \mathrm{~g}$, PVP $20 \mathrm{~g}(\mathrm{GM})$ aerated medium (Singleton et al., 2002.). After 5 days on incubation on optimal temperarures inoculants were stored at two temperatures: 4 and $25^{\circ} \mathrm{C}$ over a period of 6 months. Once a month, microbiological analysis was performed to determine the number of viable $B$. japonicum cells according to the dilution method while the average cell number was expressed as cfu per $\mathrm{ml}$.

\section{RESULTS AND DISCUSSION}

Microbiological analysis showed that in YM medium at $4{ }^{\circ} \mathrm{C}$, the number of viable cells was $4 \times 10^{9}$ at the beginning of experiment. During the months the number decreased slightly and remained at $9 \times 10^{8}$ cells at the end of the 6th 
Gabriella Kanižai Šarić et al.: Survival and viability of Bradyrhizobium japonicum in different liquid medium

month. MYM and GM at the beginning of the experiment had the same initial number of cells of $7 \times 10^{8}$, in the modified medium cell number remained at $2 \times 10^{7}$ until the end of the 6th month, while in the glycerol medium Bradyrhizobium cell number dropped to $8 \times 10^{6}$ (Graph 1.).

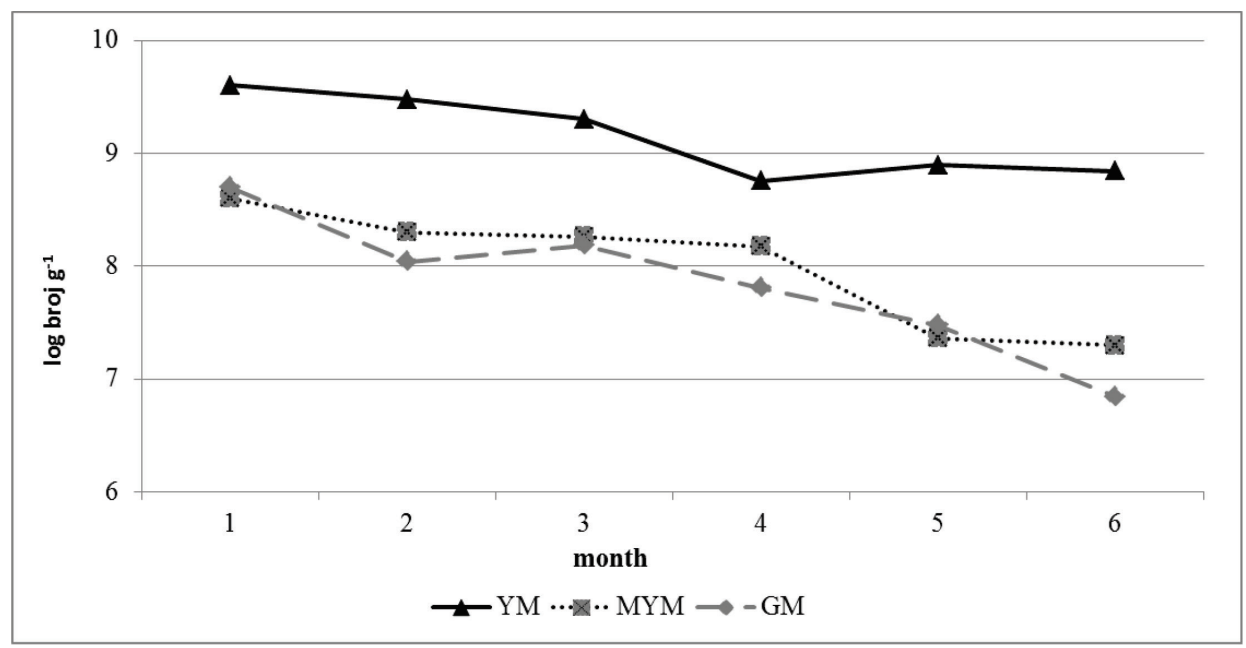

Graph 1 Viability of B. japonicum in different liquid medium at $4{ }^{\circ} \mathrm{C}$ Grafikon 1. Vijabilnost B. japonicum u različitim tekućim podlogama na $4{ }^{\circ} \mathrm{C}$

Minimum quality standards for the number of rhizobial cells varies in different countries in the range from $5 \times 10^{7}$ to $1 \times 10^{9}$ cells per gram (or ml) of freshly prepared inoculant (Lupwayi et al., 2000), although many countries, as well as the Republic of Croatia, do not have a prescribed legislative framework and quality control is carried by the producers themselves. Storage temperature is a significant factor for the survival of rhizobia and it is higher at $4-10{ }^{\circ} \mathrm{C}$ compared to $28^{\circ} \mathrm{C}$ (Herridge i sur., 2002). Also, long-term storage of rhizobial inoculants is not recommended due to the occurrence of physiological changes in rhizobial cells that may prolong the time to nodulation (Tittabutr et al., 2007). In research of Menendez et al. (2014) liquid inoculant was stable at $4{ }^{\circ} \mathrm{C}$ for at least 8 months. They increased yest extract in media and additional nitrogen salts further contributed to incraese cell density to $5 \times 10^{9} \mathrm{ml}^{-1}$. The authors also noted that exopolysaccharides are primary components of the biofilm that protects bacteria from desiccation and function as reserve energy source. 
Gabriella Kanižai Šarić et al.: Survival and viability of Bradyrhizobium japonicum in different liquid medium

A smaller number of viable cells was found at a storage temperature of $25^{\circ} \mathrm{C}$. In YM medium at $25^{\circ} \mathrm{C}$, the initial number of viable cells was $2 \times 10^{8}$ and at the end of the $6^{\text {th }}$ months it remained at $2 \times 10^{7}$. In GM the cell number was

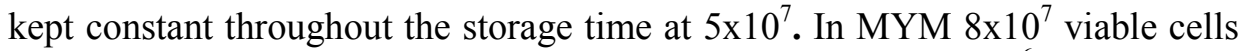
were found at the beggining of experiment which droped to $7 \times 10^{6}$ at the end of the experiment (Graph 2).

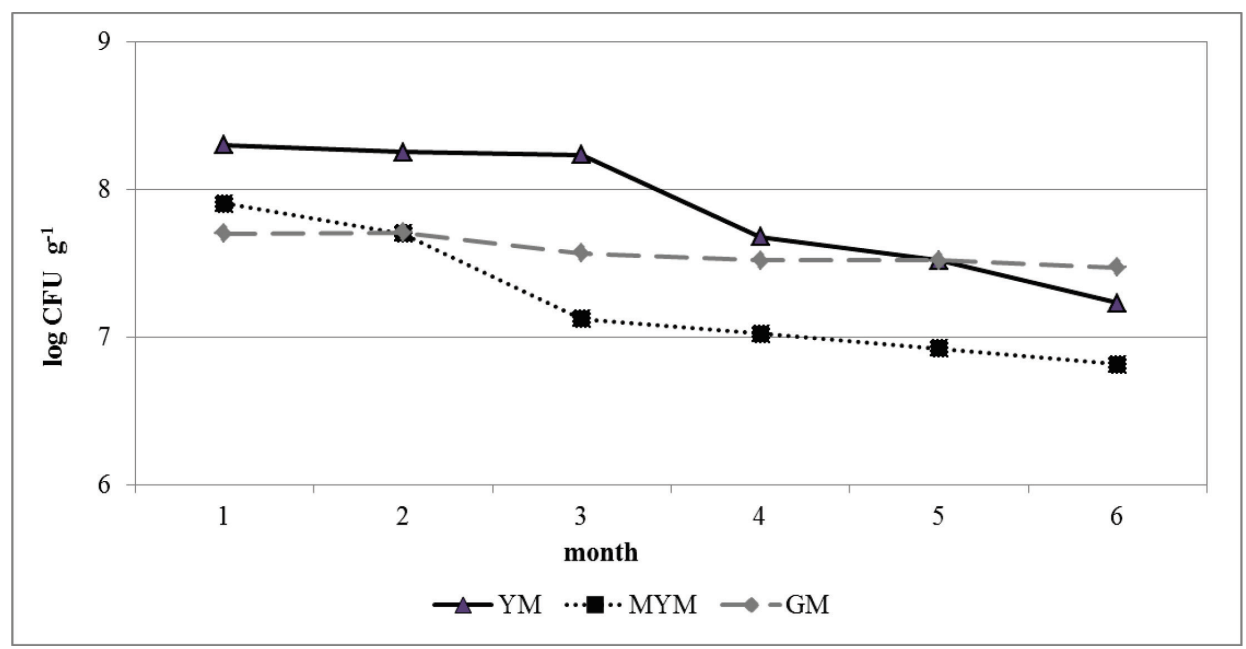

Graph 2 Viability of B. japonicum in different liquid medium at $25^{\circ} \mathrm{C}$

Grafikon 2. Vijabilnost B. japonicum u razlicitim tekućim podlogama na $25^{\circ} \mathrm{C}$

In the study of Singleton et al. (2002) after 6 months of storage the number of viable cells remained nearly constant in modified Vincent medium, glycerol and Vincent medium at $25^{\circ} \mathrm{C}\left(10^{9}, 10^{9}, 10^{8}\right)$. The authors propose that $\mathrm{C}$ and $\mathrm{N}$ starvation at the beginning of the stationary growth phase creates stress resistance in rhizobial cell. Tittabutr et al. (2007) investigated survival of rhizobia in peat and liquid inoculant (modified yaest manitol medium + PVP, cassava, alginate, PEG, arabic gum, polyvinylalcohol at $28{ }^{\circ} \mathrm{C}$. Peat based inoculants supported cell survival above $10^{8}$ cells $\mathrm{g}^{-1}$ after six months of storage and liquid inoculants modified with sodium alginate supported cell survival from $10^{5}$ to $10^{8}$ cells $\mathrm{g}^{-1}$ depending on cultivated rhizobial strain after six months of storage. Authors concluded that for commercial purpose a safe storage period of 6 months is desirable. Maurice at al. (2001) investigated 
Gabriella Kanižai Šarić et al.: Survival and viability of Bradyrhizobium japonicum in different liquid medium

survival of $B$. japonicum in commercial liquid inoculants over a period of 8 years at $20{ }^{\circ} \mathrm{C}$. Results showed that cells remained viable and culturable at $10^{8}$ cell ml ${ }^{-1}$ with cell physiological changes. More than $85 \%$ of the bacteria were unable to propagate but remained viable.

Further research is needed that will include other protective substances that provide high viability of rhizobial cells in order to increase the quality of these products. It is also necessary to investigate the effectiveness of such formulations of liquid inoculants in field conditions.

\section{CONCLUSIONS}

All tested broths stored at $4{ }^{\circ} \mathrm{C}$ showed higher viability compared to those stored at $25{ }^{\circ} \mathrm{C}$. Yeast manitol broth showed satisfactory cell viability in the 6 months of storage. Further reserach is needed to identify new, more appropriate broth medium and to identify new additives in order to improve inoculants quality with optimal number of rhizobial cells.

\section{REFERENCES}

1. Albareda, M., Rodríguez-Navarro, D. N., Camacho, M., Temprano, F. J. (2008.): Alternatives to peat as a carrier for rhizobia inoculants: solid and liquid formulations. Soil Biology and Biochemistry 40: 2771-2779.

2. Ben Rebah, F., Prevost, D., Yezza, A., Tyagi, R.D. (2007.): Agro-industrial waste materials and wastewater sludge for rhizobial inoculant production: a review. Bioresource Technology, 98: 3535-3546.

3. Blažinkov, M., Sikora, S., Sudarić, A., Mesić M., Rajnović I., Redžepović, S. (2015.): Improvement of Rhizobial Inoculants: A Key Process in Sustainable Soybean Production Agriculturae Conspectus Scientificus, 80 (1), 25-29.

4. Herridge, D., Gemell, G., Hartley, E. (2002.): Legume Inoculants and Quality Control. ACIAR Proceedings, 105-114.

5. Hungria, M., Loureiro, M.F., Mendes, I.C., Campo, R.J., Graham, P.H. (2005.): Inoculant preparation, production and application. In: Newton WE (ed) Nitrogen fixation: origins, applications and research progress, vol 4, Werner W, Newton WE (eds) Nitrogen fixation in agriculture, forestry, ecology and the environment. Springer, Dordrecht.

6. Hungria, M., Mendes, I.C. (2015.): Nitrogen Fixation with Soybean: The Perfect Symbiosis? Biological Nitrogen Fixation, Volume 2, First Edition. John Wiley \& Sons, Inc. 
Gabriella Kanižai Šarić et al.: Survival and viability of Bradyrhizobium japonicum in different liquid medium

7. Lupwayi, N.Z., Olsen, P.E., Sande, E.S., Kayser, H.H., Collins, M.M., Singleton, P.W., Rice, W.A. (2000.): Inoculant quality and its evaluation. Field Crops Research, 65: 259-270.

8. Maurice, S., Beauclair, P., Giraud, J.J., Sommer, G., Hartmann, A., Catroux, G. (2001.): Survival and change in physiological state of Bradyrhizobiu mjaponicum in soybean (Glycine max L. Merril) liquid inoculants after longterm storage. World Journal of Microbology and Biotechnology 17: 635-643.

9. Menéndez, C., Trujillo, L.E., Ramírez, R., González-Peña, D., Espinosa, D., Enriquez, G.A., Hernández, L. (2014.): Production of a liquid Bradyrhizobium japonicum inoculant with high impact on the mechanized sowing of soybean in Cuba. Biotecnology Aplications 31:116- 120.

10. Ormeño-Orrillo, E., Hungria, M., Martínez-Romero, E. (2012.): Dinitrogenfixing prokaryotes. Chapter 11. The Prokaryotes: Biodiversity and Ecology. Berlin and Heidelberg; Springer-Verlag.

11. Singleton P, Keyser H and Sande E (2002.): Development and evaluation of liquid inoculants. In: Inoculants and nitrogen fixation of legumes in Vietnam, ACIAR Proceeding 109e, D Herridge (ed), pp. 52-66, Australian Centre for International Agricultural Research, Canberra, Australia.

12. Temprano, F.J., Albareda, M., Camacho, M., Daza, A., Santamaría, C., Rodríguez Navarro, D.N. (2002.): Survival of several Rhizobium / Bradyrhizobium strains on different inoculant formulations and inoculated seeds. International Microbiology 5: 81-86.

13. Tittabutr, P., Payakaponga, W., Teaumroonga, N., Singletonb, P.W., Boonkerda, N. (2007.): Growth, Survival and Field Performance of Bradyrhizobial Liquid Inoculant Formulations with Polymeric Additives. Science Asia, 33: 69-77.

14. Vincent, J. (1970): A manual for the practical study of root nodule bacteria. International Biological Programme. Burgess and Son, Berkshire. 
Gabriella Kanižai Šarić et al.: Survival and viability of Bradyrhizobium japonicum in different liquid medium

Author's addresses - Adresa autora:

izv. prof. dr. sc. Gabriella Kanižai Šarić,

e-mail: gkanizai@fazos.hr,

izv. prof. dr. sc. Ivana Majić,

Faculty of Agrobiotechnical Sciences Osijek, Josip Juraj Strossmayer University in Osijek, Vladimira Preloga 1, Osijek, Croatia

Krešimir Prtenjača, student,

Faculty of Agrobiotechnical Sciences Osijek, Josip Juraj Strossmayer University in Osijek, Vladimira Preloga 1, Osijek, Croatia
Received - Primljeno:

09.11.2020. 